\title{
Influence of bleaching on flavor of $34 \%$ whey protein concentrate and residual benzoic acid concentration in dried whey proteins
}

\author{
M. A. D. Listiyani, ${ }^{\star}$ R. E. Campbell,, ${ }^{\star}$ R. E. Miracle, ${ }^{\star}$ L. O. Dean, $\dagger$ and M. A. Drake ${ }^{\star 1}$ \\ *Southeast Dairy Foods Research Center, Department of Food, Bioprocessing \& Nutrition Science, North Carolina State University, \\ Raleigh 27695 \\ †Market Quality and Handling Research Unit, Agricultural Research Service, US Department of Agriculture, North Carolina State University, \\ Raleigh 27695
}

\section{ABSTRACT}

Previous studies have shown that bleaching negatively affects the flavor of $70 \%$ whey protein concentrate (WPC70), but bleaching effects on lower-protein products have not been established. Benzoyl peroxide (BP), a whey bleaching agent, degrades to benzoic acid (BA) and may elevate BA concentrations in dried whey products. No legal limit exists in the United States for $\mathrm{BP}$ use in whey, but international concerns exist. The objectives of this study were to determine the effect of hydrogen peroxide (HP) or BP bleaching on the flavor of $34 \%$ WPC (WPC34) and to evaluate residual BA in commercial and experimental WPC bleached with and without BP. Cheddar whey was manufactured in duplicate. Pasteurized fat-separated whey was subjected to hot bleaching with either $\mathrm{HP}$ at $500 \mathrm{mg} / \mathrm{kg}$, BP at 50 or $100 \mathrm{mg} / \mathrm{kg}$, or no bleach. Whey was ultrafiltered and spray dried into WPC34. Color [L*(lightness), a* (redgreen), and $\mathrm{b}^{*}$ (yellow-blue)] measurements and norbixin extractions were conducted to compare bleaching efficacy. Descriptive sensory and instrumental volatile analyses were used to evaluate bleaching effects on flavor. Benzoic acid was extracted from experimental and commercial WPC34 and 80\% WPC (WPC80) and quantified by HPLC. The $\mathrm{b}^{*}$ value and norbixin concentration of BP-bleached WPC34 were lower than HP-bleached and control WPC34. Hydrogen peroxidebleached WPC34 displayed higher cardboard flavor and had higher volatile lipid oxidation products than BPbleached or control WPC34. Benzoyl peroxide-bleached WPC34 had higher BA concentrations than unbleached and HP-bleached WPC34 and BA concentrations were also higher in BP-bleached WPC80 compared with unbleached and HP-bleached WPC80, with smaller differences than those observed in WPC34. Benzoic acid extraction from permeate showed that WPC80 permeate contained more BA than did WPC34 permeate.

Received March 5, 2011

Accepted May 1, 2011.

${ }^{1}$ Corresponding author: mdrake@unity.ncsu.edu
Benzoyl peroxide is more effective in color removal of whey and results in fewer flavor side effects compared with $\mathrm{HP}$ and residual BA is decreased by ultrafiltration and diafiltration.

Key words: whey, benzoic acid, bleach, flavor

\section{INTRODUCTION}

Benzoyl peroxide $\left(\mathbf{B P} ; \mathrm{C}_{14} \mathrm{H}_{10} \mathrm{O}_{4}\right)$ is a colorless, crystalline solid used as a bleaching agent in certain foods, such as flour, whey, and milk used for certain types of cheese (JECFA, 2004a). It is also 1 of 2 currently approved chemical bleaching agents that can be used to bleach whey (Kang et al., 2010). Benzoyl peroxide is generally recognized as safe (GRAS) when used as a bleaching agent, following current Good Manufacturing Practices (GMP; US FDA, 2010b). Currently no legal limits exist for BP use established in the United States. At the sixty-third meeting, the Joint Food and Agriculture Organization/World Health Organization (FAO/WHO) Expert Committee on Food Additives (JECFA) stated that no safety concern exists for BP in whey bleaching when used at up to $100 \mathrm{mg} / \mathrm{kg}$ (JEFCA, 2004b). In Codex Alimentarius, $100 \mathrm{mg} / \mathrm{kg}$ was the maximum limit for BP bleaching of liquid whey, dried whey, and whey products, except for infant applications, where it is prohibited (Codex Alimentarius Commission, 2008). Currently, 2 bleaching agents are allowed for whey bleaching in the United States: hydrogen peroxide (maximum usage rate at $500 \mathrm{mg} / \mathrm{kg}$; US FDA, 2010c) and benzoyl peroxide (US FDA, 2010b). In comparison to hydrogen peroxide (HP), bleaching with $\mathrm{BP}$ requires less peroxide for satisfactory bleaching, does not need catalase addition to deactivate, and it is less corrosive to stainless steel equipment (Chang et al., 1977; Kang et al., 2010). Croissant et al. (2009) suggested that when applied to liquid whey, BP bleaching resulted in fewer lipid oxidation products and offflavors compared with HP.

Benzoyl peroxide breaks down to benzoic acid (BA) when it reacts with oxidizable substances present, such as annatto or carotenoid pigments during processing 
(JECFA, 2004a; Kang et al., 2010). Benzoic acid occurs naturally in many foods such as dairy products, nuts, fruits, and vegetables (Sieber et al., 1995). In fermented dairy products, it is produced from hippuric acid in milk during fermentation and, therefore, cultured dairy products, such as yogurt and smear-ripened cheeses contain some BA (Sieber et al., 1995). In yogurt, BA was detected at various levels between 12 to $47 \mathrm{mg} /$ $\mathrm{kg}$ (plain yogurt) and between 5 to $39 \mathrm{mg} / \mathrm{kg}$ (fruit yogurt; Sieber et al., 1995). Benzoic acid content varied between 10 to $18 \mathrm{mg} / \mathrm{kg}$ in sour cream, 10 to $19 \mathrm{mg} /$ $\mathrm{kg}$ in buttermilk, 8 to $23 \mathrm{mg} / \mathrm{kg}$ in kefir, and 2 to 18 $\mathrm{mg} / \mathrm{kg}$ in cottage cheese (Sieber et al., 1995). Sieber et al. (1995) also reported BA concentrations between 12 to $13 \mathrm{mg} / \mathrm{kg}$ in fluid whey and between 23 to 75 $\mathrm{mg} / \mathrm{kg}$ in whey powder, but bleaching conditions for these products were not known. Benzoic acid is GRAS (US FDA, 2010a) and it is a common preservative used widely in foods, drugs, and cosmetics (Sieber et al., 1995; Chipley, 2005; Qi et al., 2009). As a food preservative, BA is used mostly in food products that are naturally in an acidic $\mathrm{pH}$ range, such as fruit juices and soft drinks (WHO, 2000). Benzoic acid is also widely used as a preservative in toothpastes, mouthwashes, and dentifrices (WHO, 2000). Benzoic acid concentration in foods, where it was used as a preservative, did not exceed $2,000 \mathrm{mg} / \mathrm{kg}$ of food; and in foods in which it occurred naturally, its concentration did not exceed $40 \mathrm{mg} / \mathrm{kg}$ (WHO, 2000).

Although BA is GRAS, it has been reported to give adverse health effects, such as skin and eye irritation, asthma, urticaria, metabolic acidosis, and convulsions (WHO, 2000; Tfouni and Toledo, 2002; Qi et al., 2009; Lino and Pena, 2010). According to JECFA (2004b), the adverse reactions to BA-related compounds are rare, and life-threatening reactions are extremely rare. Many Asian and European countries consider BA harmful (USDEC, 2009; Kang et al., 2010). Benzoic acid levels in dried whey ingredients are concerns in China (Dairy Management Inc., 2009) and, therefore, problems exist with exporting whey products bleached with BP. The maximum level of BA in many products has also been regulated in Europe and China (EC, 1995; State Bureau for Quality Supervision, Inspection and Quarantine, 1996). In China, the maximum concentrations of BA permitted are $200 \mathrm{mg} / \mathrm{kg}$ in carbonated drinks, and 1,000 $\mathrm{mg} / \mathrm{kg}$ in juice drinks, sauces, and jams (State Bureau for Quality Supervision, Inspection and Quarantine, 1996). The European Commission (EC) has allowed the use of $\mathrm{BP}$ as a bleaching agent; however, the regulations per individual country may vary (Kang et al., 2010). Taiwan has permitted the use of $\mathrm{BP}$ as a bleaching agent in whey powder since 1999 (Johnson, 2006). Chinese authorities, on the other hand, have banned the use of BP as a bleaching agent and do not allow the presence of BA in whey products (USDEC, 2009; McKnight, 2010). Currently, the US Dairy Export Council (USDEC) has requested China's Ministry of Health for permission to use BP as a bleaching agent (McKnight, 2010). China's Ministry of Health is currently in the process of developing new standards for whey protein concentrate (WPC) and whey protein isolate, and the specific permitted level of BA has not been determined (NMPF and USDEC, 2009; McKnight, 2010).

A method for the determination of BA in foods using liquid chromatography (LC) was developed in the 1980s (Bui and Cooper, 1987). More current methods for BA testing in whey powder involve reconstitution of the powdered sample, precipitation of fats and proteins using zinc acetate and potassium hexacyanoferrate(II) trihydrate, filtration of the sample, and separation using a C-18 HPLC column with UV and visible (UV-VIS) detection (ISO, 2008; Qi et al., 2009). High performance liquid chromatography is the most common separation technique used because it has high sensitivity, requires minimum sample preparation, and no sample derivatization is needed (WHO, 2000).

Previous studies have suggested that BP bleaching of fluid whey results in fewer off-flavors in $80 \%$ WPC (WPC80) compared with HP bleaching of fluid whey. However, specific effects on 34\% WPC (WPC34) have not been evaluated. Further, comparisons of BA residues in WPC34 and WPC80, where the specific bleaching agent is known, have not been published. The objectives of this study were to evaluate the effect of bleaching agent on bleaching efficacy and flavor of WPC34 and to determine the influence of bleaching agent on BA concentration in dried whey proteins.

\section{MATERIALS AND METHODS}

\section{Experimental Design}

Influence of Bleaching on Color and Flavor of WPC34. Whey protein concentrates (34\%) manufactured from colored Cheddar whey with no bleach, HP bleach, and BP bleach were manufactured in duplicate at the North Carolina State University Dairy Plant (Raleigh). Color, sensory, and volatile analyses were conducted to determine the influence of bleaching and bleaching agent on WPC34 color and flavor.

Benzoic Acid Residues. In a subsequent experiment, BA residues in dried whey proteins were compared. Commercial WPC34 and WPC80 (less than $60 \mathrm{~d}$ old, duplicate lots) were obtained from at least 3 different manufacturing facilities. Pilot plant-manufactured WPC80 were obtained in triplicate from D. M. Bar- 
bano (Cornell University, Ithaca, NY) and were manufactured as described by Evans et al. (2010), with $60^{\circ} \mathrm{C}$ bleaching for $1 \mathrm{~h}$ applied with the bleaching agent and concentration indicated. The WPC34 manufactured for the first part of this study were also used as samples. The bleaching agents used and bleaching conditions of pilot plant-manufactured WPC34 and WPC80 were known. In the case of commercial whey proteins, the bleaching agent (HP or BP or no bleach) was known, but the bleaching conditions and concentrations were proprietary.

\section{Experimental WPC34 Manufacture}

Raw whole milk was obtained from the North Carolina State University Dairy Plant. Milk $(150 \mathrm{~kg})$ was vat-pasteurized (Model MPD1050, Micro Process Design; D \& F Equipment Co., McLeansville, NC) at $63^{\circ} \mathrm{C}$ for $30 \mathrm{~min}$. The milk was cooled to $35^{\circ} \mathrm{C}$ and Cheddar cheese manufacture was initiated. The pasteurized milk was adjusted to $31^{\circ} \mathrm{C}$ in a cheese vat (model MX4; Kusel Equipment Co., Watertown, WI). Calcium chloride (50\% wt/vol; Dairy Connection Inc., Madison, WI) at the rate of $0.39 \mathrm{~mL} / \mathrm{kg}$ of milk and mesophilic lactic starter (Choozit MA 11; Danisco USA Inc., New Century, KS) at 50 Danisco culture units (DCU)/454 kg of milk were added and the cheese was ripened for 60 min. After the first $30 \mathrm{~min}$ of ripening, 1:20 diluted double strength annatto (Chr. Hansen Inc., Milwaukee, WI) was added $(0.066 \mathrm{~mL} / \mathrm{kg}$ of milk). The milk was then coagulated for 30 min using 1:80 diluted recombinant rennet (Dairy Connection Inc., Madison, WI) at the rate of $0.09 \mathrm{~mL} / \mathrm{kg}$ of milk at the end of the ripening period. Following coagulation, the cheese curd was cut using $0.95-\mathrm{cm}$ knives and healed for $5 \mathrm{~min}$. The curds were stirred gently for $10 \mathrm{~min}$ and cooked by increasing the temperature to $39^{\circ} \mathrm{C}$ across $30 \mathrm{~min}$. The $\mathrm{pH}$ and titratable acidity were monitored closely, and the liquid whey was drained at $\mathrm{pH}$ 6.4. The liquid Cheddar whey obtained was then pasteurized at $63^{\circ} \mathrm{C}$ for $30 \mathrm{~min}$, followed by fat removal using a hot bowl separator (Westfalia Separator; C.A. De Fehr \& Sons Ltd., Winnipeg, Manitoba, Canada) to obtain $90 \mathrm{~kg}$ of fat-separated whey.

The separated whey was portioned into 2 batches of $45 \mathrm{~kg}$ each. Each portion was transferred into a stainless vat (Fermenator; Blichmann Engineering, Lafayette, IN) equipped with a coil heater. The whey was heated to $60^{\circ} \mathrm{C}$ and 1 of 4 treatments was conducted: no bleach for the control whey, $500 \mathrm{mg}$ of HP $/ \mathrm{kg}(35 \%$ wt/vol; Nelson Jameson Inc., Marshfield, WI), or 50 or $100 \mathrm{mg}$ of $\mathrm{BP} / \mathrm{kg}$ (32\% wt/wt, Oxylite type XX; Nelson Jameson Inc., Marshfield, WI). The liquid whey was bleached during UF, and conditions were congru- ent with time and temperatures that can be applied industrially for whey bleaching (Kang et al., 2010). The UF system (model Pellicon 2; Millipore Inc., Billerica, MA) was equipped with 4 polyethersulfone cartridge membrane filters (model P2B010V05, $10 \mathrm{kDa}$ nominal separation cutoffs, $0.5 \mathrm{~m}^{2}$ surface area; Millipore Inc.). Each sample was run through a peristaltic pump (model 77410-10; Cole-Palmer Instrument Co., Vernon Hills, IL) into separate pump heads (model 77601-00; Cole-Palmer Instrument Co.) and the UF assembly using silicone tubing (model 96440-73; Cole-Palmer Instrument Co.) that was connected to the Fermenator. This process continued until the retentate reached 38 to $39 \%$ protein content confirmed by a Sprint rapid protein analyzer (CEM USA, Matthews, NC; approx $2 \mathrm{~h}$ ). Catalase was added to the HP-bleached whey $(20 \mathrm{mg} /$ kg, Food Pro CAT; Danisco USA Inc.) and stirred. The absence of HP was confirmed by testing with a peroxide strip (EMD Chemicals Inc.; VWR International, West Chester, PA). Three liters of retentate was then collected from each treatment and spray dried (model Lab 1; Anhydro Inc., Søborg, Denmark).

The retentate was sent to the spray drier through a hose (Model 06402-73) that went through a peristaltic pump (Model 85MHP40; Stenner Pump Co., Jacksonville, FL) and connected to a valve (Pneu-Trol, Bellwood, IL) to regulate a continuous flow for spray drying at a rate of approximately $1 \mathrm{~kg} / \mathrm{h}$. The inlet temperature was at $150^{\circ} \mathrm{C}$ and the outlet temperature was at $80^{\circ} \mathrm{C}$. Total spray-drying time was approximately $1.5 \mathrm{~h}$. The spray-dried whey was evaluated on a Sprint rapid protein analyzer (CEM USA) to ensure that the protein content was $34 \% \mathrm{wt} / \mathrm{wt}$. The powder was sealed in Mylar bags and stored at $-80^{\circ} \mathrm{C}$. Two treatments were conducted from one lot of milk and cheese, so it took $2 \mathrm{~d}$ to complete the entire experimental replication. The order of treatment manufacture was randomized and the entire experiment was replicated twice. The experimental WPC34 were evaluated in duplicate for composition analysis (moisture, fat, protein, and mineral); norbixin content; L* (lightness), a* (red-green), and $b^{*}$ (yellow-blue) color values; descriptive sensory analysis; and volatile compound analysis [solid-phase microextraction (SPME) GC-MS], in addition to BA analysis.

\section{Composition Analysis}

Total solids, fat, and protein analyses were conducted in duplicate on experimental WPC34. The samples were reconstituted to $10 \%$ solids. The TS were analyzed using forced-air oven drying (AOAC, 2000; method 990.20; 33.2.44), fat content was analyzed by ether extraction (AOAC, 2000; method 989.05; 33.2.26), and 
the protein (total nitrogen, or $\mathrm{TN}$ ) was analyzed using the Kjeldahl method (AOAC 2000; method 991.20; 33.2.11). Mineral analysis (phosphorus, calcium, magnesium, potassium, sulfur, iron, sodium, and ash) was determined by the North Carolina State University Analytical Services Laboratory (Raleigh) using a standard dry ash method with inductively coupled plasma optical emission spectroscopy (Lloyd et al., 2009). The moisture content of each sample was calculated from the TS and the protein and fat were calculated on both dry- and wet-weight bases. Percent lactose and mineral contents were calculated by subtracting moisture, protein, and fat from 100.

\section{Color Analysis and Norbixin Extraction and Measurement}

Color values $\mathrm{L}^{*}, \mathrm{a}^{*}$, and $\mathrm{b}^{*}$ were measured in $\mathrm{du}-$ plicate using a MacBeth Color-Eye spectrophotometer (model 2020; Kollmorgen Instruments Corp., Newburgh, NY) equipped with Optiview software. The reflectance method used illuminant $\mathrm{A}$ and the wavelength was set at 380 to $760 \mathrm{~nm}$ range at $20-\mathrm{nm}$ intervals. A white reference tile was used as the background when measuring the reflectance. Duplicate measurements were conducted on both the powder and the $10 \%$ (wt/ vol) reconstituted powders.

Norbixin extractions and measurements were conducted in duplicate on experimental WPC34 as described by Campbell et al. (2011). Briefly, $2 \mathrm{~mL}$ of HPLC-grade water (Honeywell Burdick \& Jackson, Muskegon, MI) was added to $1 \mathrm{~g}$ of WPC34 sample and vortexed (Labnet International Inc., Woodbridge, NJ). Six milliliters of ethanol (99.5\%; EMD Chemicals Inc., Gibbstown, NJ) was then added to the sample and vortexed for 30 $\mathrm{s}$. The sample was held for $30 \mathrm{~min}$ at room temperature and then $3 \mathrm{~mL}$ of chloroform (EMD Chemicals Inc.) was added. The sample was vortexed and centrifuged at $11,970 \times g$ for $10 \mathrm{~min}$ at $4^{\circ} \mathrm{C}$. The supernatant was collected into another centrifuge tube and another 3 $\mathrm{mL}$ of chloroform was added to the remaining volume, which was then centrifuged again at $16,500 \times g$ for $10 \mathrm{~min}$. More supernatant was collected and combined with previously collected supernatant. Two milliliters of $1 \%$ acetic acid $(99.5 \%$; J. T. Baker Chemicals, Phillipsburg, NJ) was added to the collected supernatant and it was vortexed and centrifuged at $16,500 \times g$ for $10 \mathrm{~min}$. The volume of the bottom layer, which was the chloroform layer containing norbixin, was measured, collected, and subjected to solid-phase extraction. The solid-phase extraction column [Strata $\mathrm{NH}_{2} \quad(55 \mu \mathrm{m}$, 70A) $500 \mathrm{mg} / 3 \mathrm{~mL}$; Phenomenex Inc., Torrance, CA) was conditioned with $7 \mathrm{~mL}$ of $n$-hexane (Fisher Scientific Inc., Pittsburgh, PA) before $1 \mathrm{~mL}$ of sample was added to the column. Then the column was rinsed with $5 \mathrm{~mL}$ of 1:1 (vol/vol) $n$-hexane:diethyl ether (EMD Chemicals Inc.) and $1 \mathrm{~mL}$ of acetone (EMD Chemicals Inc.) to wash out the fat and $\beta$-carotene. The norbixin was then eluted with $3 \mathrm{~mL}$ of $7: 3$ ( $\mathrm{vol} / \mathrm{vol})$ methanol (EMD Chemicals Inc.):glacial acetic acid (99.5\%, J. T. Baker Chemicals) and collected. The absorbance of the sample was measured in duplicate using a UV-VIS Spectrophotometer (UV-1700 PharmaSpec; Shimadzu Scientific Instruments, Columbia, MD) at $458 \mathrm{~nm}$. The concentration of norbixin recovery was calculated based on the absorbance and standard curve.

\section{Descriptive Sensory Analysis}

Descriptive sensory analysis $(\mathrm{n}=10)$ was conducted in compliance with the North Carolina State University Institutional Review Board for human subjects approval. Samples were evaluated in duplicate by 8 panelists (ages 22-46 yr, 7 females, 1 male) who each had more than $150 \mathrm{~h}$ of experience with descriptive analysis of dried dairy ingredient aroma and flavor, including WPC, using the spectrum method (Drake and Civille, 2003; Meilgaard et al., 2007). The aroma and flavor attributes of reconstituted WPC34 were evaluated using a 0- to 15-point scale and an established lexicon for dried dairy ingredients (Carunchia-Whetstine et al., 2003, 2005; Drake et al., 2003; Russell et al., 2006; Evans et al., 2009). Rehydrated WPC34 (10\% wt/vol) was dispensed into 60-mL lidded soufflé cups (ca 30 $\mathrm{mL}$ ) labeled with 3 -digit random codes. These samples were tempered to $20^{\circ} \mathrm{C}$ and served at this temperature. Panelists were instructed to expectorate samples after evaluation. Deionized water and unsalted crackers were available to the panelists for palate cleansing. Each replicate was evaluated in duplicate by each panelist in a randomized block design using paper ballots or Compusense five, version 4.8 software (Compusense Inc., Guelph, ON, Canada).

\section{Volatile Compound Analysis}

Volatile compounds were extracted by SPME, followed by GC-MS. This method was adapted from Croissant et al. (2009). Ten percent (wt/wt) sodium chloride (VWR International) was added to 20-mL SPME autosampler vials (MicroLiter Analytical Supplies Inc., Suwanee, GA). Five grams of rehydrated sample $(10 \%$ wt/wt) was then added to the vial, followed by $10 \mu \mathrm{L}$ of $8.1 \mathrm{mg} / \mathrm{kg}$ internal standard [2-methyl-3-heptanone (Sigma-Aldrich, St. Louis, MO) dissolved in methanol (EMD Chemicals Inc.)]. The vial was then capped with a screw-top cap equipped with Teflon septa (MicroLiter Analytical Supplies Inc.). The extracted volatiles were 
separated by GC-MS (model 6890N; Agilent Technologies Inc., Cary, NC), equipped with a 5973 mass selective detector and a DB-5 column (30-m length, $0.25-\mathrm{mm}$ i.d., and $0.25-\mu \mathrm{m}$ film thickness; Restek Corp., Bellefonte, PA), equipped with a Combi PAL autosampler (CTC Analytics, Zwingen, Switzerland). Samples were maintained at $5^{\circ} \mathrm{C}$ before exposure with a divinylbenzene (DVB)/Carboxen/polydimethylsiloxane (PDMS) StableFlex fiber (Supelco Inc., Bellefonte, PA). Samples were equilibrated at $40^{\circ} \mathrm{C}$ for $25 \mathrm{~min}$ before $1 \mathrm{~cm}$ of fiber was exposed for $30 \mathrm{~min}$ at $31 \mathrm{~mm}$. While the fiber was exposed to the sample, the vial was agitated at $250 \mathrm{rpm}$ with 4 -s agitation pulse. Then, the fiber was inserted at $50 \mathrm{~mm}$ for $5 \mathrm{~min}$ at $250^{\circ} \mathrm{C}$ into the split/splitless injector, running in splitless mode. Helium gas was used as the carrier gas at a rate of 1 $\mathrm{mL} / \mathrm{min}$. The initial GC oven temperature was $40^{\circ} \mathrm{C}$ for $3 \mathrm{~min}$. The temperature was then increased to $90^{\circ} \mathrm{C}$ at a rate of $10^{\circ} \mathrm{C} / \mathrm{min}$ and then to $200^{\circ} \mathrm{C}$ at $5^{\circ} \mathrm{C} / \mathrm{min}$. This temperature was held for $10 \mathrm{~min}$. The temperature was then increased again to $250^{\circ} \mathrm{C}$ at $20^{\circ} \mathrm{C} / \mathrm{min}$ and was held for $5 \mathrm{~min}$. The total run time was $52 \mathrm{~min}$ per sample.

Retention indices were calculated (Van den Dool and Kratz, 1963) based on an alkane series (SigmaAldrich Corp.). Scan mode and the National Institute of Standards and Technology mass spectral library (NIST, 2005) were used to initially identify the volatile compounds of interest. Selective ion monitoring (SIM) mode was then used for higher sensitivity to pick out specific compounds of interest (Croissant et al., 2009; Campbell et al., 2011). In addition, authentic standards were injected under identical conditions to verify the identity of volatile compounds. The relative abundance of compounds was determined by comparing their area to the area of the known concentration of the recovered internal standard. These analyses were conducted in triplicate.

\section{Benzoic Acid Extractions and Measurements}

Benzoic acid from all experimental and commercial dried whey proteins and also from liquid permeates from the experimental WPC34 and WPC80 manufacture was extracted in duplicate, based on a method adapted from the ISO 9231 method (2008) and Qi et al. (2009). The sample $(2.5 \mathrm{~g})$ was weighed into a centrifuge tube (VWR International) and $15 \mathrm{~mL}$ of HPLC-grade water at $40^{\circ} \mathrm{C}$ (Honeywell Burdick \& Jackson) was added to it. The reconstituted sample was vortexed (Labnet International Inc.) and transferred to a $50-\mathrm{mL}$ volumetric flask (VWR International). Two more $10-\mathrm{mL}$ portions of LC-MS-grade water were added to the tube, vortexed, and transferred to the volumetric flask to rinse the rest of the sample from the tube. Five milliliters of $1 M$ zinc acetate solution (Mallinckrodt Baker Inc., Phillipsburg, NJ) followed by $5 \mathrm{~mL}$ of $0.25 \mathrm{M}$ potassium hexacyanoferrate(II) trihydrate (Alfa Aesar, Ward Hill, MA) in water solution were added to the sample to precipitate fat and protein. Zinc acetate solution was made by weighing $21.9 \mathrm{~g}$ of zinc acetate, adding $32 \mathrm{~mL}$ of acetic acid (99.5\%; Mallinckrodt Baker Inc.), and diluting it with HPLC water to $100-\mathrm{mL}$ total volume. Once the zinc acetate and potassium hexacyanoferrate solutions were added, the sample was diluted with LCMS-grade water to $50 \mathrm{~mL}$ and shaken manually for 1 min. The sample was then filtered using vacuum filtration through a $0.45-\mu \mathrm{m}$ polyethersulfone (PES) membrane (VWR International). The filtrate was collected for analysis and diluted 1:1 with the HPLC mobile phase and placed into a 1.5-mL HPLC vial (Alltech Associates Inc., Deerfield, IL).

The analysis was carried out using a Dionex HPLC system (Dionex Corp., Sunnyvale, CA) equipped with a P680 pump, ASI-100 autosampler, UVD340U diode array detector, and Phenomenex HyperClone ODS (C18) $120 \mathrm{~A}$ column $(4.0 \times 250 \mathrm{~mm}, 5 \mu \mathrm{m})$ with a $\mathrm{C} 18$ security guard $(4 \times 2.0 \mathrm{~mm}$; Phenomenex Inc.). The column oven temperature was kept at $30^{\circ} \mathrm{C}$. The mobile phase used was $4 \%$ (vol/vol) methanol (Mallinckrodt Baker Inc.) and $96 \%$ (vol/vol) ammonium acetate buffer (0.02M; Sigma-Aldrich Corp.) with a flow rate of $1.0 \mathrm{~mL} / \mathrm{min}$. The injection volume of the sample was $20 \mu \mathrm{L}$. The UV detector was set at 230 -nm wavelength.

A standard curve for BA was constructed for the concentrations of $0.050,0.10,0.15,0.20,0.25,0.5,1.0,2.5$, $5.0,10,25$, and $50 \mathrm{mg} / \mathrm{kg}$. For this standard, BA (EMD Chemicals Inc.) at different concentrations was made up in the mobile phase solution. The extracted samples were injected in duplicate. Benzoic acid concentrations were calculated based on the standard curve and dilution factor using Chromeleon 6.8 Chromatography Data System (Dionex Corp.). In addition to this, some commercial and experimental WPC34 and WPC80 samples were rehydrated and spiked with BA standard (10 mg/ $\mathrm{kg}$ ), extracted and injected, and used to calculate BA recovery. The limit of detection (LOD) was calculated based on the blank sample signal plus 3 standard deviations of the blank. The spectra shown in the sample peak as well as retention time were also compared with those in the standard solutions. This method was used to extract and measure the $\mathrm{BA}$ residue in all of the commercial and experimental samples. The concentration of BA was calculated based on the area of the peak and the standard curve generated. Dilution factors of the sample in the extraction procedure $(2.5: 50)$ and the extract injected (1:2), in addition to the recovery, were taken into account in calculating the BA concentration. 


\section{Statistical Analyses}

Data were analyzed using ANOVA with means separation (XLSTAT, version 2009.1.02; Addinsoft Inc., New York, NY). Principal component analysis (PCA) was also conducted to visually illustrate volatile compounds differences in experimental WPC34.

\section{RESULTS AND DISCUSSION}

\section{Composition Analysis}

No differences were detected in composition of experimental WPC34 $(P>0.05)$. Mean moisture, fat, and protein contents were $2.37 \pm 0.66 \% ; 1.64 \pm 0.07 \%$ (dry wt), $1.48 \pm 0.06 \%$ (wet wt); and $33.7 \pm 1.3 \%$ (dry wt), $30.4 \pm 1.2 \%$ (wet wt), respectively. Lactose and mineral contents (combined) of WPC34 were $65.8 \pm$ $1.4 \%$. No differences were found $(P>0.05)$ in mineral components tested, except for iron (Table 1). Hydrogen peroxide-bleached WPC34 had lower iron content compared with the unbleached WPC34 $(P<0.05)$. This result suggests that some reaction between HP and whey components occurs that releases iron or allows more iron to be removed during UF.

\section{Color Analysis and Norbixin Extractions and Measurements}

Visually, no differences were observed between WPC34 powders (Figure 1); however, significant differences in color were observed between rehydrated bleached and unbleached WPC34 samples (Figure 2). Similarly, the Hunter $\mathrm{L}^{*}, \mathrm{a}^{*}$, and $\mathrm{b}^{*}$ color values of bleached and unbleached WPC34 powders were not different, but differences $(P<0.05)$ in $\mathrm{b}^{*}$ values were observed between the reconstituted samples (Table 2). Reconstituted WPC34 (10\% wt/vol), bleached with BP at either concentration (50 or $100 \mathrm{mg} / \mathrm{kg}$ ), had lower reflectance $\left(\mathrm{b}^{*}\right)$ values compared with the control unbleached WPC34 $(P<0.05)$, whereas the HP bleached WPC34 was not different from the control unbleached WPC34 $(P>0.05)$. The WPC34 bleached with HP or $\mathrm{BP}$ had lower norbixin concentration compared with the unbleached WPC34 $(P<0.05$; Figure 3$)$ and bleaching with $\mathrm{BP}$ decreased the norbixin concentration of WPC34 more than did HP bleaching $(P<0.05)$. These results are consistent with those observed by Croissant et al. (2009) for WPC70.

\section{Descriptive Sensory Analysis}

Sensory profiles of rehydrated WPC34 (10\% solids) were distinct (Table 3 ). These flavors have previously been documented in dried whey ingredients (Drake et al., 2003, 2009; Evans et al., 2009; Wright et al., 2009). The unbleached WPC34 had higher sweet aromatic and cooked/milky flavors compared with bleached WPC34 $(P<0.05)$, and the HP bleached WPC34 had higher cardboard flavor compared with unbleached and BPbleached samples (Table 3). Higher cardboard flavor in HP-bleached fluid whey and WPC70 compared with control or BP-bleached product has been documented previously (Croissant et al., 2009).

\section{Volatile Compound Analysis}

Twenty-five volatile compounds were selected for analysis based on previous studies with fluid whey and dried whey ingredients (Carunchia Whetstine et al., 2003, 2005; Wright et al., 2006, 2009; Croissant et al., 2009; Evans et al., 2009, 2010; Leksrisompong et al., 2010; Liaw et al., 2010; Campbell et al., 2011). These compounds included a range of fermentation flavor compounds (i.e., diacetyl, acetic acid, and butanoic acid), as well as protein oxidation (dimethyl disulfide and dimethyl trisulfide), Strecker degradation products (i.e., 3-methylbutanal and 2-methylbutanal), and lipid oxidation products (i.e., aldehydes, alcohols, and ketones). The WPC34 bleached with HP had higher concentrations of lipid oxidation compounds, including pentanal, hexanal, heptanal, and octanal, compared with unbleached WPC34 and WPC34 bleached with 50 or $100 \mathrm{mg}$ of $\mathrm{BP} / \mathrm{kg}$ (Table 4). The WPC34 bleached with $100 \mathrm{mg}$ of $\mathrm{BP} / \mathrm{kg}$, in many cases, had higher concentrations of lipid oxidation compounds than WPC34 bleached with $50 \mathrm{mg}$ of $\mathrm{BP} / \mathrm{kg}$ (Table 4). Whey bleached with $500 \mathrm{mg}$ of $\mathrm{HP} / \mathrm{kg}$ and $100 \mathrm{mg}$

Table 1. Mineral analysis of experimental 34\% whey protein concentrate (WPC34)

\begin{tabular}{|c|c|c|c|c|c|c|c|c|}
\hline Sample ${ }^{1}$ & $\mathrm{P}(\%)$ & $\mathrm{Ca}(\%)$ & $\operatorname{Mg}(\%)$ & $\mathrm{K}(\%)$ & $\mathrm{S}(\%)$ & $\begin{array}{c}\mathrm{Fe} \\
(\mathrm{mg} / \mathrm{kg})\end{array}$ & $\begin{array}{c}\mathrm{Na} \\
(\mathrm{mg} / \mathrm{kg})\end{array}$ & $\begin{array}{l}\text { Ash } \\
(\mathrm{g})\end{array}$ \\
\hline Control & $0.601^{\mathrm{a}}$ & $0.740^{\mathrm{a}}$ & $0.113^{\mathrm{a}}$ & $1.87^{\mathrm{a}}$ & $0.440^{\mathrm{a}}$ & $17.4^{\mathrm{a}}$ & $5.51 \times 10^{3 \mathrm{a}}$ & $0.175^{\mathrm{a}}$ \\
\hline HP 500 & $0.596^{\mathrm{a}}$ & $0.735^{\mathrm{a}}$ & $0.111^{\mathrm{a}}$ & $1.84^{\mathrm{a}}$ & $0.458^{\mathrm{a}}$ & $5.48^{\mathrm{b}}$ & $5.72 \times 10^{3 \mathrm{a}}$ & $0.175^{\mathrm{a}}$ \\
\hline BP 50 & $0.597^{\mathrm{a}}$ & $0.751^{\mathrm{a}}$ & $0.112^{\mathrm{a}}$ & $1.80^{\mathrm{a}}$ & $0.446^{\mathrm{a}}$ & $7.99^{\mathrm{ab}}$ & $5.26 \times 10^{3 \mathrm{a}}$ & $0.131^{\mathrm{a}}$ \\
\hline BP 100 & $0.592^{\mathrm{a}}$ & $0.764^{\mathrm{a}}$ & $0.113^{\mathrm{a}}$ & $1.76^{\mathrm{a}}$ & $0.463^{\mathrm{a}}$ & $12.5^{\mathrm{ab}}$ & $5.20 \times 10^{3 \mathrm{a}}$ & $0.171^{\mathrm{a}}$ \\
\hline
\end{tabular}

$\overline{\mathrm{a}, \mathrm{b}}$ Means in the same column not sharing a common superscript are significantly different $(P<0.05)$.

${ }^{1}$ Control $=$ no bleach; HP $500=$ hydrogen peroxide $(500 \mathrm{mg} / \mathrm{kg}) ;$ BP 50 and BP $100=$ benzoyl peroxide $(50$ and $100 \mathrm{mg} / \mathrm{kg}$, respectively). 


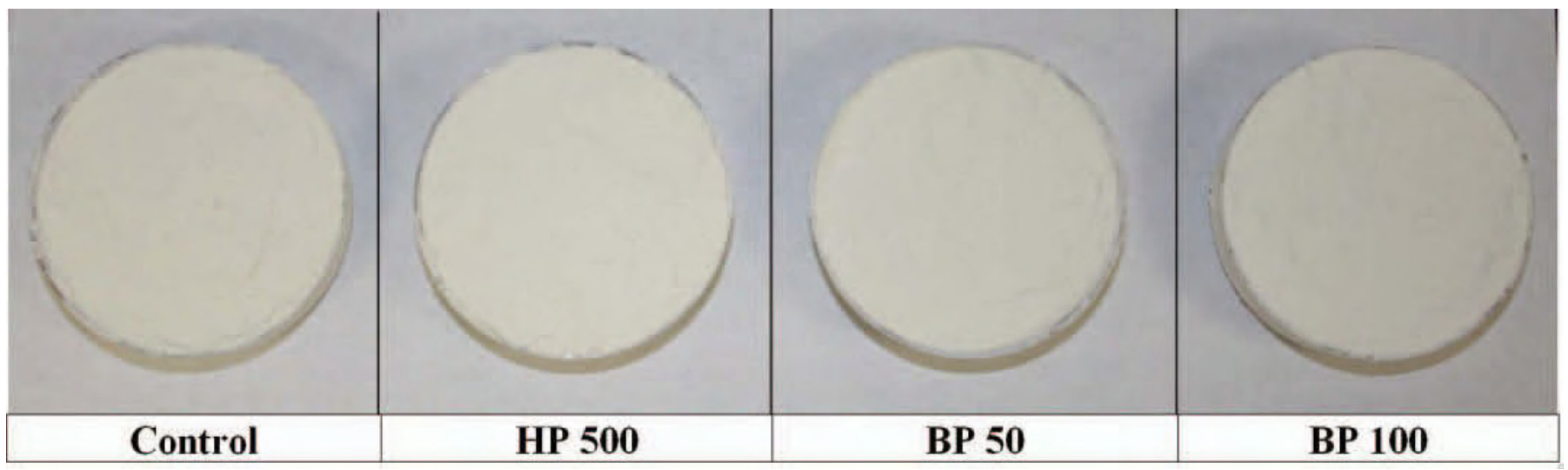

Figure 1. Experimental 34\% whey protein concentrate (WPC34) powders. Control = no bleach; HP $500=$ hydrogen peroxide $(500 \mathrm{mg} / \mathrm{kg})$; $\mathrm{BP} 50$ and $\mathrm{BP} 100=$ benzoyl peroxide $(50$ and $100 \mathrm{mg} / \mathrm{kg}$, respectively). Color version available in the online PDF.

of $\mathrm{BP} / \mathrm{kg}$ were more characterized by lipid oxidation compounds, whereas the unbleached whey and those bleached with $\mathrm{BP}$ at $50 \mathrm{mg} / \mathrm{kg}$ were characterized by lower concentrations of lipid oxidation compounds (Figure 4). These volatile compound results are consistent with sensory profiles, which indicated higher cardboard flavors in HP-bleached WPC34 compared with unbleached or BP-bleached product. Cardboard flavor has been sourced to lipid oxidation compounds in fluid whey and dried whey ingredients (Wright et al., 2009; Liaw et al., 2010; Whitson et al., 2010).

Lipid oxidation is initiated in the cheese-making process (Tomaino et al., 2004). The unsaturated fatty acids, such as oleic, linoleic, and linolenic acids from the milk can form unstable hydroperoxides, which decompose to carbonyl products, such as short-chain fatty acids and aldehydes (Badings, 1991; O'Connor and O'Brien, 2006). In whey bleaching, HP reacts with UV light or transition metals in milk and creates hydroxyl radicals (McClements and Decker, 2008), whereas BP undergoes hemolytic cleavage of the oxygen-oxygen bond, producing benzoyl radicals (Croissant et al., 2009). These peroxides can abstract hydrogen from carotenoid double bonds and, thereby, remove color or form alkyl radicals in lipids and promote oxidation. These alkyl radicals react with oxygen to form peroxyl radicals, which further abstract more hydrogen from another molecule to form hydroperoxides (Frankel, 1998). These hydroperoxides then decompose to volatile oxidation products (Nawar, 1996; Frankel, 1998). Overall, BP-bleached WPC34 had lower norbixin concentration than HP-bleached WPC34, and WPC34 bleached with HP resulted in higher lipid oxidation and cardboard flavor compared with unbleached and BP-bleached samples.

\section{Benzoic Acid Analysis}

The instrumental LOD for BA solution was $0.05 \mathrm{mg} /$ $\mathrm{kg}$. The LOD for BA was $12.5 \mathrm{mg} / \mathrm{kg}$ in WPC and 5.42 $\mathrm{mg} / \mathrm{kg}$ in permeate. Bui and Cooper (1987) reported

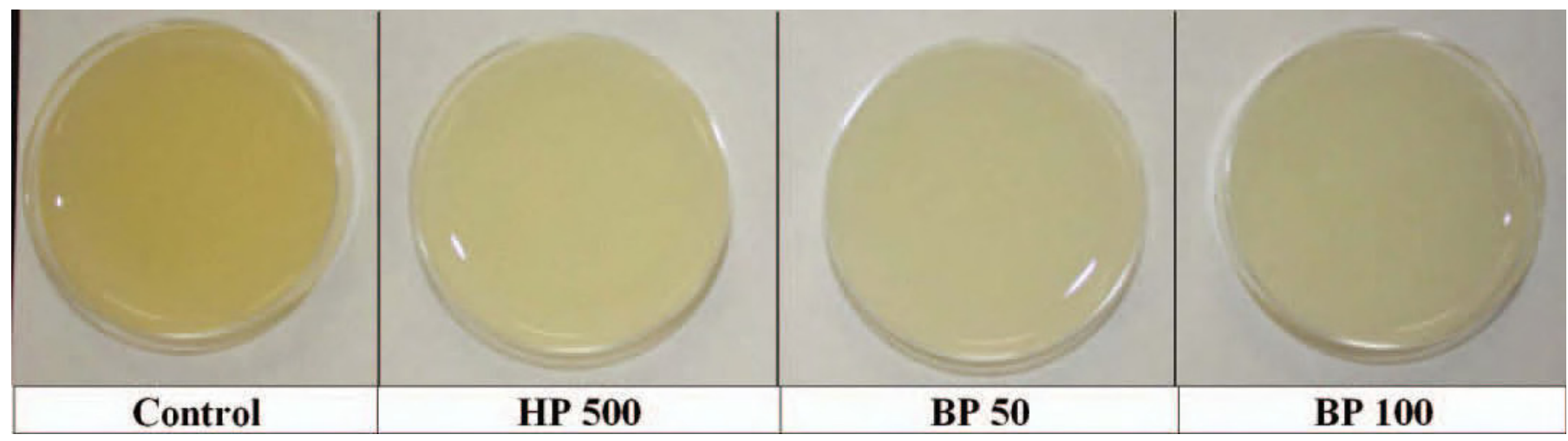

Figure 2. Experimental reconstituted $34 \%$ whey protein concentrate (WPC34) at $10 \%$ solids (wt/vol). Control $=$ no bleach; HP $500=$ hydrogen peroxide $(500 \mathrm{mg} / \mathrm{kg})$; BP 50 and BP $100=$ benzoyl peroxide $(50$ and $100 \mathrm{mg} / \mathrm{kg}$, respectively). Color version available in the online PDF. 
Table 2. Hunter L* (lightness), a* (red-green), and $b^{*}$ (yellow-blue) color values of experimental bleached and unbleached Cheddar 34\% whey protein concentrate (WPC34) as powders and reconstituted to $10 \%$ solids (wt/vol)

\begin{tabular}{|c|c|c|c|c|c|c|}
\hline \multirow{2}{*}{$\begin{array}{l}\text { Bleaching } \\
\text { treatment }^{1}\end{array}$} & \multicolumn{3}{|c|}{ Powder } & \multicolumn{3}{|c|}{ Reconstituted powder $[10 \%$ solids (wt/vol) $]$} \\
\hline & $\mathrm{L}^{*}$ & $a^{*}$ & $b^{*}$ & $\mathrm{~L}^{*}$ & $\mathrm{a}^{*}$ & $b^{*}$ \\
\hline Control & $89.5^{\mathrm{a}}$ & $1.80^{\mathrm{a}}$ & $10.8^{\mathrm{a}}$ & $43.5^{\mathrm{a}}$ & $-0.438^{\mathrm{a}}$ & $11.9^{\mathrm{a}}$ \\
\hline HP 500 & $91.7^{\mathrm{a}}$ & $1.07^{\mathrm{a}}$ & $10.2^{\mathrm{a}}$ & $45.9^{\mathrm{a}}$ & $-2.52^{\mathrm{a}}$ & $8.51^{\mathrm{ab}}$ \\
\hline BP 50 & $89.6^{\mathrm{a}}$ & $0.733^{\mathrm{a}}$ & $9.36^{\mathrm{a}}$ & $44.3^{\mathrm{a}}$ & $-2.40^{\mathrm{a}}$ & $6.30^{\mathrm{b}}$ \\
\hline BP 100 & $90.5^{\mathrm{a}}$ & $0.473^{\mathrm{a}}$ & $8.02^{\mathrm{a}}$ & $47.6^{\mathrm{a}}$ & $-3.76^{\mathrm{a}}$ & $4.08^{\mathrm{b}}$ \\
\hline
\end{tabular}

$\overline{\mathrm{a}, \mathrm{b}}$ Means in the same column not sharing a common superscript are significantly different $(P<0.05)$.

${ }^{1}$ Control $=$ no bleach; HP $500=$ hydrogen peroxide $(500 \mathrm{mg} / \mathrm{kg}) ; \mathrm{BP} 50$ and BP $100=$ benzoyl peroxide $(50$ and $100 \mathrm{mg} / \mathrm{kg}$, respectively).

that the LOD for BA was $20 \mathrm{mg} / \mathrm{kg}$ in complex foods such as dairy products and $5 \mathrm{mg} / \mathrm{kg}$ in less complex matrixes such as soft drinks. Qi et al. (2009) reported that the LOD for BA was $0.2 \mathrm{mg} / \mathrm{kg}$ from pasteurized and UHT-treated milk and $2 \mathrm{mg} / \mathrm{kg}$ for milk powder and infant formula.

Experimental and commercial WPC34 that were bleached with BP had higher BA residue compared with the unbleached or HP-bleached WPC34 $(P<0.05$; Table 5). Benzoic acid content in both experimental and commercial WPC34 ranged from less than 12.5 to $634 \mathrm{mg} / \mathrm{kg}$ (Table 5). The unbleached and HP-bleached WPC34 had lower BA contents than the range reported by Sieber et al. (1995): 12 to $13 \mathrm{mg} / \mathrm{kg}$ in whey and from 23 to $75 \mathrm{mg} / \mathrm{kg}$ in whey powder. The BA content in commercial Mozzarella WPC34 were within this range, whereas the BP-bleached samples had higher $\mathrm{BA}$ content than this previously reported range. The experimental BP-bleached $(50 \mathrm{mg} / \mathrm{kg})$ WPC34 had a comparable amount of $\mathrm{BA}$ content to commercial BPbleached WPC34. However, the actual amount of BP added to the commercial samples was unknown. The experimental BP-bleached WPC80 had higher BA content than unbleached and HP-bleached WPC80 $(P<$ 0.05; Table 6). The BA content in WPC80 that was not colored with annatto was lower than the BA concentration from annatto colored WPC80 $(P<0.05$; Table $6)$. This result may suggest that in annatto-colored whey, benzoyl peroxide preferentially reacts with conjugated double bonds present in annatto as oxidizable substances; and benzoyl peroxide decomposes to BA, resulting in higher BA content in the final product compared with product with no annatto. Alternatively, this result may reflect that $\mathrm{BP}$ is a large and relatively nonpolar molecule. The presence of annatto with its nonpolar regions may allow the BP to be more available for reaction.

Benzoic acid contents in commercial WPC80 were lower than the range of what was reported by Sieber et al. (1995), except for the experimental BP-bleached WPC80, which were within this range. The values reported by Sieber et al. (1995) did not include whether the whey was bleached or unbleached and whether the whey came from Cheddar or Mozzarella cheese. Differences in BA contents found in the current study and those found by Sieber et al. (1995) may possibly be due to different amounts of hippuric acid present in the milk as well as starter culture used and the concentration of bleaching agent used. Qi et al. (2009) stated that BA content in fluid milk and cultured milk

Table 3. Descriptive sensory profiles of bleached and unbleached Cheddar $34 \%$ whey protein concentrate $(\mathrm{WPC} 34)^{1}$

\begin{tabular}{lccccc}
\hline $\begin{array}{l}\text { Bleaching } \\
\text { treatment }\end{array}$ & $\begin{array}{c}\text { Aroma } \\
\text { intensity }\end{array}$ & $\begin{array}{c}\text { Sweet } \\
\text { aromatic }\end{array}$ & Cardboard & $\begin{array}{c}\text { Cooked } \\
\text { milky }\end{array}$ & Astringent \\
\hline Control & $2.2^{\mathrm{a}}$ & $2.2^{\mathrm{a}}$ & $\mathrm{ND}^{3}$ & $2.6^{\mathrm{a}}$ & $1.0^{\mathrm{a}}$ \\
HP 500 & $2.0^{\mathrm{a}}$ & $0.9^{\mathrm{b}}$ & $1.8^{\mathrm{a}}$ & $1.9^{\mathrm{b}}$ & $1.0^{\mathrm{a}}$ \\
BP 50 & $1.3^{\mathrm{b}}$ & $1.0^{\mathrm{b}}$ & $0.6^{\mathrm{b}}$ & $2.0^{\mathrm{b}}$ & $1.0^{\mathrm{a}}$ \\
BP 100 & $1.2^{\mathrm{b}}$ & $1.1^{\mathrm{b}}$ & $1.0^{\mathrm{b}}$ & $1.9^{\mathrm{b}}$ & $1.2^{\mathrm{a}}$ \\
\hline
\end{tabular}

${ }_{\mathrm{a}, \mathrm{b}}$ Means in the same column not sharing a common superscript are significantly different $(P<0.05)$.

${ }^{1}$ Intensities were scored based on a 0 - to 15 -point universal scale, with 0 being no intensity and 15 being the highest intensity. Most dried ingredient flavors fall between 0 and 4 on this scale (Evans et al., 2009; Wright et al., 2009; Liaw et al., 2010).

${ }^{2}$ Control $=$ no bleach; HP $500=$ hydrogen peroxide $(500 \mathrm{mg} / \mathrm{kg}) ; \mathrm{BP} 50$ and BP $100=$ benzoyl peroxide $(50$ and $100 \mathrm{mg} / \mathrm{kg}$, respectively).

${ }^{3}$ Not detected. 
Table 4. Relative abundance $(\mu \mathrm{g} / \mathrm{kg})$ of selected volatile compounds in bleached and unbleached spray dried Cheddar 34\% whey protein concentrate (WPC34)

\begin{tabular}{|c|c|c|c|c|}
\hline \multirow[b]{2}{*}{ Compound } & \multicolumn{4}{|c|}{ Treatment $^{1}$} \\
\hline & Control & HP 500 & BP 50 & BP 100 \\
\hline 3-Methyl butanal & $0.159^{\mathrm{a}}$ & $0.080^{\mathrm{b}}$ & $0.024^{\mathrm{b}}$ & $0.045^{\mathrm{b}}$ \\
\hline 2-Methyl butanal & $0.120^{\mathrm{a}}$ & $0.065^{\mathrm{b}}$ & $0.026^{\mathrm{b}}$ & $0.037^{\mathrm{b}}$ \\
\hline Pentanal & $0.025^{\mathrm{c}}$ & $0.182^{\mathrm{a}}$ & $0.053^{\mathrm{bc}}$ & $0.086^{\mathrm{b}}$ \\
\hline Hexanal & $4.11^{\mathrm{b}}$ & $32.1^{\mathrm{a}}$ & $18.8^{\mathrm{ab}}$ & $32.6^{\mathrm{a}}$ \\
\hline Z-4-heptenal & $0.018^{\mathrm{a}}$ & $0.015^{\mathrm{a}}$ & $0.009^{\mathrm{a}}$ & $0.013^{\mathrm{a}}$ \\
\hline Heptanal & $0.575^{\mathrm{b}}$ & $2.87^{\mathrm{a}}$ & $0.989^{\mathrm{b}}$ & $2.69^{\mathrm{a}}$ \\
\hline Benzaldehyde & $0.242^{\mathrm{a}}$ & $0.231^{\mathrm{a}}$ & $0.075^{\mathrm{a}}$ & $0.290^{\mathrm{a}}$ \\
\hline Octanal & $0.094^{\mathrm{b}}$ & $0.934^{\mathrm{a}}$ & $0.160^{\mathrm{b}}$ & $0.472^{\mathrm{b}}$ \\
\hline Phenylacetaldehyde & $0.122^{\mathrm{a}}$ & $0.063^{\mathrm{b}}$ & $0.026^{\mathrm{b}}$ & $0.067^{\mathrm{ab}}$ \\
\hline 2-Octenal & $0.013^{\mathrm{b}}$ & $0.217^{\mathrm{a}}$ & $0.096^{\mathrm{ab}}$ & $0.197^{\mathrm{a}}$ \\
\hline Nonanal & $1.45^{\mathrm{a}}$ & $1.98^{\mathrm{a}}$ & $1.23^{\mathrm{a}}$ & $2.56^{\mathrm{a}}$ \\
\hline E-2-nonenal & $0.030^{\mathrm{a}}$ & $0.101^{\mathrm{a}}$ & $0.052^{\mathrm{a}}$ & $0.119^{\mathrm{a}}$ \\
\hline Decanal & $0.038^{\mathrm{a}}$ & $0.053^{\mathrm{a}}$ & $0.031^{\mathrm{a}}$ & $0.056^{\mathrm{a}}$ \\
\hline E,E-2,4-nonadienal & $0.008^{\mathrm{b}}$ & $0.092^{\mathrm{ab}}$ & $0.051^{\mathrm{ab}}$ & $0.127^{\mathrm{a}}$ \\
\hline Diacetyl & $0.064^{\mathrm{a}}$ & $0.038^{\mathrm{a}}$ & $0.038^{\mathrm{a}}$ & $0.039^{\mathrm{a}}$ \\
\hline Acetic acid & $0.103^{\mathrm{a}}$ & $0.096^{\mathrm{a}}$ & $0.091^{\mathrm{a}}$ & $0.106^{\mathrm{a}}$ \\
\hline Dimethyl disulfide (DMDS) & $0.045^{\mathrm{b}}$ & $0.095^{\mathrm{a}}$ & $0.008^{\mathrm{c}}$ & $0.023^{\mathrm{bc}}$ \\
\hline 1-Pentanol & $0.076^{\mathrm{b}}$ & $0.181^{\mathrm{b}}$ & $0.256^{\mathrm{b}}$ & $0.584^{\mathrm{a}}$ \\
\hline Butanoic acid & $0.026^{\mathrm{a}}$ & $0.012^{\mathrm{a}}$ & $0.015^{\mathrm{a}}$ & $0.010^{\mathrm{a}}$ \\
\hline 2-Heptanone & $0.370^{\mathrm{a}}$ & $0.373^{\mathrm{a}}$ & $0.274^{\mathrm{a}}$ & $0.357^{\mathrm{a}}$ \\
\hline Hexanoic acid & $0.065^{\mathrm{a}}$ & $0.077^{\mathrm{a}}$ & $0.070^{\mathrm{a}}$ & $0.074^{\mathrm{a}}$ \\
\hline 1-Octen-3-one & $0.029^{\mathrm{b}}$ & $0.178^{\mathrm{ab}}$ & $0.116^{\mathrm{ab}}$ & $0.185^{\mathrm{a}}$ \\
\hline Dimethyl trisulfide (DMTS) & $0.085^{\mathrm{a}}$ & $0.097^{\mathrm{a}}$ & $0.092^{\mathrm{a}}$ & $0.110^{\mathrm{a}}$ \\
\hline 2,5 -Octanedione & $0.117^{\mathrm{b}}$ & $0.340^{\mathrm{ab}}$ & $0.197^{\mathrm{ab}}$ & $0.460^{\mathrm{a}}$ \\
\hline 2-Pentylfuran & $0.559^{\mathrm{b}}$ & $3.716^{\mathrm{a}}$ & $1.446^{\mathrm{b}}$ & $3.916^{\mathrm{a}}$ \\
\hline
\end{tabular}

${ }^{\mathrm{a}-\mathrm{c}}$ Means in the same row not sharing a common superscript are significantly different $(P<0.05)$.

${ }^{1}$ Control $=$ no bleach; HP $500=$ hydrogen peroxide $(500 \mathrm{mg} / \mathrm{kg}) ; \mathrm{BP} 50$ and $\mathrm{BP} 100=$ benzoyl peroxide $(50$ and $100 \mathrm{mg} / \mathrm{kg}$, respectively).

products could be influenced by various factors, including feeding practices (preservatives used in feeds), contamination, and storage conditions. In comparing WPC34 and WPC80, BA concentrations in WPC34

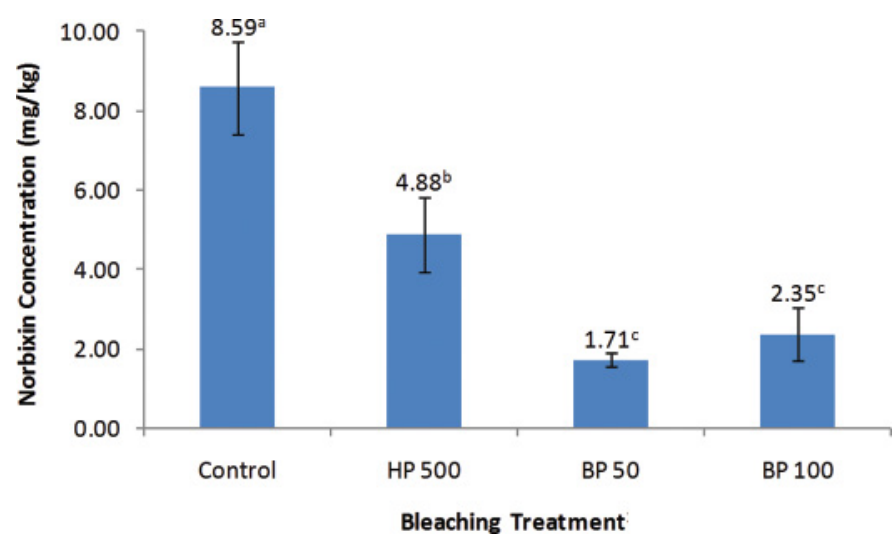

Figure 3. Norbixin recovery $(\mathrm{mg} / \mathrm{kg})$ from bleached or unbleached $34 \%$ whey protein concentrate (WPC34). ${ }^{\mathrm{a}-\mathrm{c}}$ Means not sharing a common letter are significantly different $(P<0.05)$. Control $=$ no bleach; HP $500=$ hydrogen peroxide $(500 \mathrm{mg} / \mathrm{kg}) ; \mathrm{BP} 50$ and BP $100=$ benzoyl peroxide (50 and $100 \mathrm{mg} / \mathrm{kg}$, respectively). Color version available in the online PDF. were higher than in WPC80, even at the same concentration of BP and under similar bleaching time/ temperature application (Table 5 and 6 ). This result suggested to us that residual BA from BP bleaching may be removed by UF and diafiltration and we then examined liquid permeates for BA. From BA extraction of WPC34 and WPC80 permeates, the BA concentration in BP-bleached WPC34 permeate was lower than in BP-bleached WPC80 permeate $(P<0.05$; Table 7). The BA content in WPC34 and WPC80 permeate supported the results of higher BA concentrations in WPC34 compared with WPC80 powder and suggested that BA was removed by UF and diafiltration. Benzoic acid concentration in liquid retentates with and without BP bleaching was not measured. However, if $100 \%$ reaction of $\mathrm{BP}$ is assumed, the amount of $\mathrm{BA}$ in the $50 \mathrm{mg}$ of $\mathrm{BP} / \mathrm{kg}$ treatment would be $7096.88 \mathrm{mg}$ of $\mathrm{BP}$ reagent added $\times 0.32$ (purity of the $\mathrm{BP}$ reagent) $=2,271 \mathrm{mg}$ of $\mathrm{BP}$. When this is converted to moles and then back to $\mathrm{mg}$ of BA, assuming $2 \mathrm{~mol}$ of $\mathrm{BA} /$ mol of BP, 2,271 mg of BA would be expected. The total actual amount of $\mathrm{BA}$ in the $50 \mathrm{mg}$ of $\mathrm{BP} / \mathrm{kg}$ of WPC34, taking into account the yield of WPC34, was $194 \mathrm{mg}$, whereas that of permeate was $779 \mathrm{mg}$. This result suggests that some BP did not get converted to BA 
Table 5. Benzoic acid concentration $(\mathrm{mg} / \mathrm{kg})$ in experimental and commercial spray dried $34 \%$ whey protein concentrate (WPC34)

\begin{tabular}{lc}
\hline Sample $^{1}$ & $\begin{array}{c}\text { Benzoic acid } \\
\text { concentration } \\
(\mathrm{mg} / \mathrm{kg})\end{array}$ \\
\hline Experimental $^{\text {Control }(\text { Cheddar, no bleach) }}$ & $<12.5$ \\
Cheddar, HP-bleached $(500 \mathrm{mg} / \mathrm{kg})$ & $<12.5$ \\
Cheddar, BP-bleached $(50 \mathrm{mg} / \mathrm{kg})$ & $272^{\mathrm{b}}$ \\
Cheddar, BP-bleached $(100 \mathrm{mg} / \mathrm{kg})$ & $634^{\mathrm{a}}$ \\
Commercial & $12.7^{\mathrm{c}}$ \\
Mozzarella, no bleach & $27.6^{\mathrm{b}}$ \\
Mozzarella, no bleach & $<12.5$ \\
Cheddar, no bleach & $278^{\mathrm{a}}$ \\
Cheddar, BP-bleached & \\
\hline
\end{tabular}

${ }^{\mathrm{a}-\mathrm{c}}$ Means in the same sample category (experimental or commercial) not sharing a common superscript are significantly different $(P<0.05)$.

${ }^{1} \mathrm{HP}=$ hydrogen peroxide; $\mathrm{BP}=$ benzoyl peroxide.

during processing or that BA loss occurs at some point in processing. Benzoyl peroxide is not soluble in whey and requires a carrier. The whey was bleached during UF and constant circulation and agitation occurred at $60^{\circ} \mathrm{C}$, but perhaps incomplete reaction of $\mathrm{BP}$ occurred. Future studies should clarify this issue if BP remains a viable bleaching agent in the whey industry.
Benzoic acid contents in unbleached Mozzarella whey protein were generally higher than those in unbleached Cheddar whey protein, possibly due to different starter cultures used. In Mozzarella cheese making, a thermophilic starter culture is used, whereas in Cheddar cheese making, a mesophilic starter culture is used. The unbleached and HP-bleached WPC still contained some

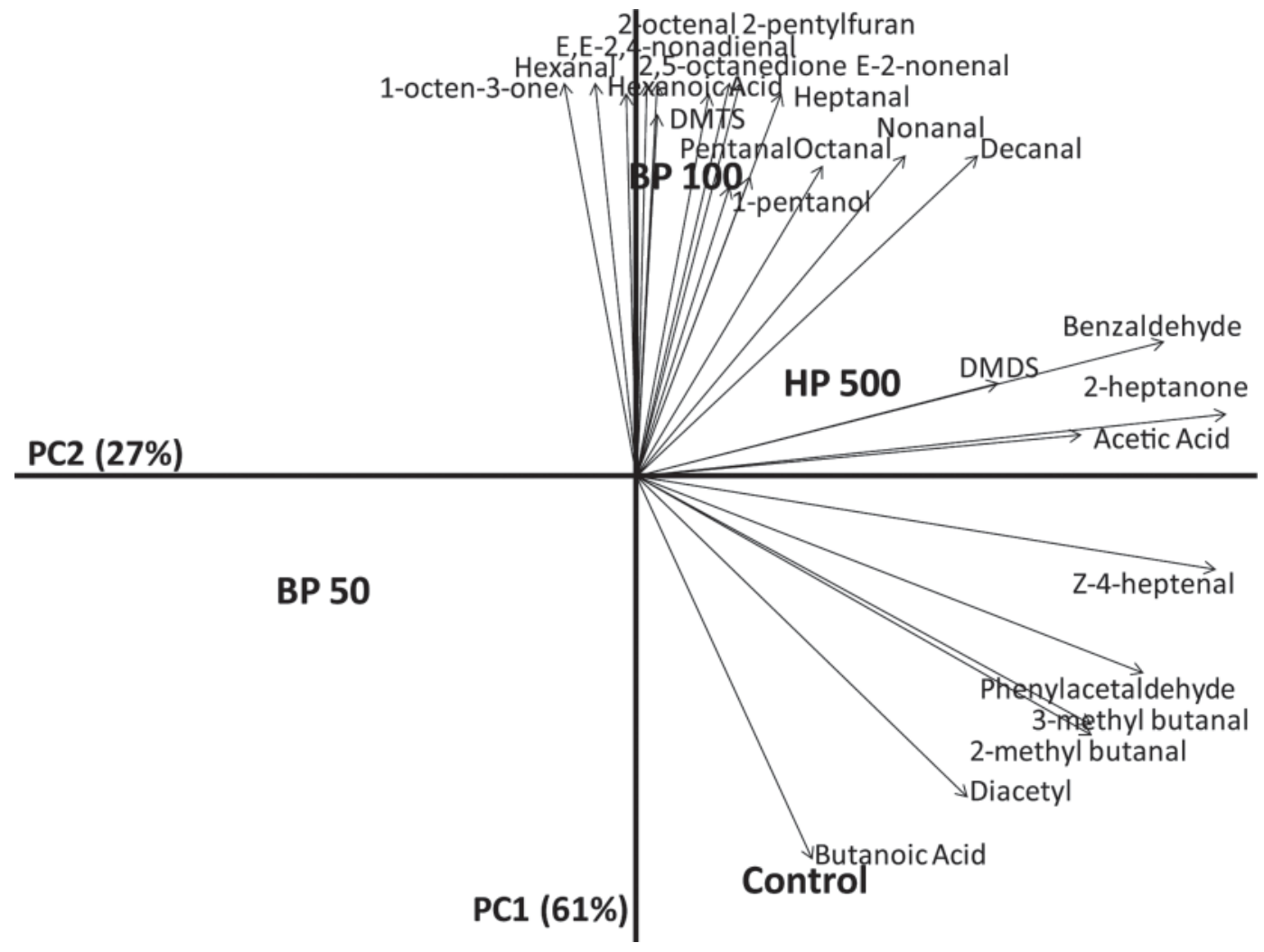

Figure 4. Principal component analysis $(\mathrm{PCA})$ biplot of volatile compounds in bleached and unbleached Cheddar WPC34. Control $=$ no bleach; HP $500=$ hydrogen peroxide $(500 \mathrm{mg} / \mathrm{kg}) ; \mathrm{BP} 50$ and BP $100=$ benzoyl peroxide $(50$ and $100 \mathrm{mg} / \mathrm{kg}$, respectively); PC1 = principal component $1 ; \mathrm{PC} 2=$ principal component 2 . 
Table 6. Benzoic acid concentration $(\mathrm{mg} / \mathrm{kg})$ in experimental and commercial spray-dried $80 \%$ whey protein concentrate (WPC80)

\begin{tabular}{lc}
\hline & $\begin{array}{c}\text { Benzoic acid } \\
\text { concentration } \\
(\mathrm{mg} / \mathrm{kg})\end{array}$ \\
Sample $^{1}$ & \\
\hline Experimental & $<12.5$ \\
Cheddar, NA, no bleach & $<12.5$ \\
Cheddar, NA, HP-bleached $(500 \mathrm{mg} / \mathrm{kg})$ & $30.6^{\mathrm{b}}$ \\
Cheddar, NA, BP-bleached $(50 \mathrm{mg} / \mathrm{kg})$ & $<12.5$ \\
Cheddar, A, no bleach & $<12.5$ \\
Cheddar, A, HP-bleached $(500 \mathrm{mg} / \mathrm{kg})$ & $60.0^{\mathrm{a}}$ \\
Cheddar, A, BP-bleached $(50 \mathrm{mg} / \mathrm{kg})$ & $<12.5$ \\
Commercial & $<12.5$ \\
Mozzarella, no bleach & $<12.5$ \\
Cheddar, no bleach & $<12.5$ \\
Cheddar, no bleach & $<12.5$ \\
Cheddar, no bleach & $<12.5$ \\
Cheddar, HP-bleached & $<12.5$ \\
Mixed, HP-bleached & $<$ \\
Mixed, HP-bleached & \\
${ }_{\text {a,b }}$ Means in the same sample category (experimental or commercial) not sharing a common superscript are \\
significantly different $(P<0.05)$. & \\
${ }^{1}$ NA = no annatto; A = annatto; HP = hydrogen peroxide; BP = benzoyl peroxide.
\end{tabular}

BA. This BA is likely from conversion of hippuric acid that is naturally present in the milk to BA by starter bacteria (Sieber et al., 1995).

\section{CONCLUSIONS}

Our results demonstrate that $\mathrm{BP}$ at both concentrations tested (50 and $100 \mathrm{mg} / \mathrm{kg}$ ) is a more effective bleaching agent compared with HP at its highest allowable concentration $(500 \mathrm{mg} / \mathrm{kg})$ as a bleaching agent for fluid whey. Descriptive sensory analysis demonstrated that HP-bleached WPC34 had higher cardboard flavor, followed by $100 \mathrm{mg}$ of $\mathrm{BP} / \mathrm{kg}, 50 \mathrm{mg}$ of $\mathrm{BP} / \mathrm{kg}$, and unbleached WPC34. Consistent with sensory results, WPC34 bleached with HP at $500 \mathrm{mg} / \mathrm{kg}$ and BP at 100 $\mathrm{mg} / \mathrm{kg}$ had more lipid oxidation products compared with the unbleached and $50 \mathrm{mg}$ of $\mathrm{BP} / \mathrm{kg}$-bleached WPC34. Experimental and commercial WPC34 samples bleached with BP had higher BA residue compared with unbleached and HP-bleached WPC34 $(P<0.05)$. The annatto-colored experimental WPC80 bleached with $\mathrm{BP}$ was higher in $\mathrm{BA}$ content compared with the unbleached and HP-bleached WPC80 $(P<0.05)$. Benzoic acid extraction from permeate demonstrated that WPC80 permeate contained more BA than WPC34 permeate $(P<0.05)$. Overall, these results suggest that BP is a more effective bleaching agent compared with HP; that whey bleaching with HP will result in increased lipid oxidation compared with BP; and that residual $\mathrm{BA}$ is decreased by $\mathrm{UF}$ and diafiltration.

\section{ACKNOWLEDGMENTS}

Funding was provided by the Dairy Research Institute (DRI) managed by Dairy Management Inc. (Rosemont, IL). Special thanks to Dje Yobouet (USDA, Agricultural Marketing Service-Field Laboratory Services, Gastonia, NC) and Ping Qi (Institute of Food Industry Hygiene Inspection, Guangzhou, Guangdong Province, China) for their assistance with HPLC, and to David Barbano (Cornell University, Ithaca, NY) for his assistance with composition analysis and for providing the experimental WPC80 samples. The use of trade names

Table 7. Benzoic acid concentration $(\mathrm{mg} / \mathrm{kg})$ in experimental $34 \%$ whey protein concentrate (WPC34) and 80\% WPC (WPC80) liquid permeates

\begin{tabular}{lc}
\hline Sample $^{1}$ & $\begin{array}{c}\text { Benzoic acid } \\
\text { concentration } \\
(\mathrm{mg} / \mathrm{kg})\end{array}$ \\
\hline WPC34 & \\
Control & $<5.42$ \\
HP 500 & $<5.42$ \\
BP 50 & $19.1^{\mathrm{b}}$ \\
BP 100 & $20.6^{\mathrm{b}}$ \\
WPC80 (annatto) & $<5.42$ \\
Control & $<5.42$ \\
HP 500 & $37.9^{\mathrm{a}}$ \\
BP 50 & \\
\hline
\end{tabular}

${ }^{\mathrm{a}, \mathrm{b}}$ Means not sharing a common superscript are significantly different $(P<0.05)$.

${ }^{1}$ Control $=$ no bleach; HP $500=$ hydrogen peroxide $(500 \mathrm{mg} / \mathrm{kg}) ; \mathrm{BP}$ 50 and $\mathrm{BP} 100=$ benzoyl peroxide $(50$ and $100 \mathrm{mg} / \mathrm{kg}$, respectively). 
does not imply endorsement or lack of endorsement by those not mentioned.

\section{REFERENCES}

AOAC. 2000. Official Methods of Analysis. 17th ed. Association of Official Analytical Chemists, Gaithersburg, MD.

Badings, H. T. 1991. Milk. Pages 91-106 in Volatile Compounds in Foods and Beverages. H. Maarse, ed. Marcel Dekker Inc., New York, NY

Bui, L. V., and C. Cooper. 1987. Reverse-phase liquid chromatographic determination of benzoic and sorbic acids in foods. J. Assoc. Off. Anal. Chem. 70:892-896.

Campbell, R. E., R. E. Miracle, and M. A. Drake. 2011. The impact of starter culture and annatto on the flavor and functionality of whey protein concentrate. J. Dairy Sci. 94:1185-1193.

Carunchia Whetstine, M. E., A. E. Croissant, and M. A. Drake. 2005 Characterization of dried whey protein concentrate and isolate flavor. J. Dairy Sci. 88:3826-3839.

Carunchia Whetstine, M. E., J. Parker, M. A. Drake, and D. K. Larick. 2003. Determining flavor and flavor variability in commercially produced liquid Cheddar whey. J. Dairy Sci. 86:439-448.

Chang, J. E., E. G. Hammond, and G. W. Reinbold. 1977. Reactions of benzoyl peroxide with whey. J. Dairy Sci. 60:40-44.

Chipley, J. R. 2005. Sodium benzoate and benzoic acid. Pages 11-48 in Antimicrobials in Foods. 3rd ed. P. M. Davidson, J. N. Sofos, and A. L. Branen, ed. Marcel Dekker Inc., New York, NY.

Codex Alimentarius Commission. 2008. Codex General Standard for Food Additives: Codex Stan 192-1995. Accessed Sep. 22, 2010. http://www.codexalimentarius.net/gsfaonline/CXS_192e.pdf.

Croissant, A. E., E. J. Kang, R. E. Campbell, E. Bastian, and M. A. Drake. 2009. The effect of bleaching agent on the flavor of liquid whey and whey protein concentrate. J. Dairy Sci. 92:5917-5927.

Dairy Management Inc. 2009. China testing for the presence of benzoic acid. US Dairy Export Council member alert. US Dairy Export Council, Arlington, VA.

Drake, M. A., and G. V. Civille. 2003. Flavor lexicons. Compr. Rev Food Sci. Food Safety 2:33-40.

Drake, M. A., Y. Karagul-Yuceer, K. R. Cadwallader, G. V. Civille, and P. S. Tong. 2003. Determination of the sensory attributes of dried milk powders and dairy ingredients. J. Sens. Stud. 18:199 216.

Drake, M. A., R. E. Miracle, and J. M. Wright. 2009. Sensory properties of dairy proteins. Pages 429-448 in Milk Proteins: From Expression to Food. A. Thompson, M. Boland, and H. Singh, ed. Elsevier, Amsterdam, the Netherlands.

EC (European Communities). 1995. European Parliament and Council Directive No. 95/2/EC. European Communities, Brussels, Belgium.

Evans, J., J. Zulewska, M. Newbold, M. A. Drake, and D. M. Barbano. 2009. Comparison of composition, sensory, and volatile components of thirty-four percent whey protein and milk serum protein concentrates. J. Dairy Sci. 92:4773-4791.

Evans, J., J. Zulewska, M. Newbold, M. A. Drake, and D. M. Barbano. 2010. Comparison of composition and sensory properties of $80 \%$ whey protein and milk serum protein concentrates. J. Dairy Sci. 93:1824-1843

Frankel, E. N. 1998. Hydroperoxide decomposition. Pages $55-77$ in Lipid Oxidation. The Oily Press, Dundee, Scotland.

ISO. 2008. Milk and milk products - Determination of the benzoic and sorbic acid contents. Standard 9231. International Organization for Standardization, Geneva, Switzerland.

JECFA (Joint FAO/WHO Expert Committee on Food Additives). 2004a. Benzoyl peroxide. FAO chemical and technical assessment (CTA). Joint Food and Agriculture Organization/World Health Organization (FAO/WHO) Expert Committee on Food Additives.

JECFA (Joint FAO/WHO Expert Committee on Food Additives). 2004b. Evaluation of Certain Food Additives. WHO technical report series; 928. Joint Food and Agriculture Organization/World
Health Organization (FAO/WHO) Expert Committee on Food Additives. WHO, Geneva, Switzerland.

Johnson, L. 2006. Idaho agriculture trade issues report. Idaho State Department of Agriculture, Boise.

Kang, E. J., R. E. Campbell, E. Bastian, and M. A. Drake. 2010. Invited review: Annatto usage and bleaching in dairy foods. J. Dairy Sci. 93:3891-3901

Leksrisompong, P. P., R. E. Miracle, and M. A. Drake. 2010. Characterization of flavor of whey protein hydrolysates. J. Agric. Food Chem. 58:6318-6327.

Liaw, I. W.. H. Eshpari, P. S. Tong, and M. A. Drake. 2010. The impact of antioxidant addition on flavor stability of Cheddar and Mozzarella whey and Cheddar whey protein concentrate. J. Food Sci. 75:C559-C569.

Lino, C. M., and A. Pena. 2010. Occurrence of caffeine, saccharin, benzoic acid and sorbic acid in soft drinks and nectars in Portugal and subsequent exposure assessment. Food Chem. 121:503-508.

Lloyd, M. A., M. A. Drake, and P. D. Gerard. 2009. Flavor variability and flavor stability of U.S.-produced whole milk powder. J. Food Sci. 74:S334-S343.

McClements, D. J., and E. A. Decker. 2008. Lipids. Pages 155-216 in Fennema's Food Chemistry. 4th ed. S. Damodaran, K. L. Parkin, and O. R. Fennema, ed. CRC Press, Boca Raton, FL.

McKnight, M. 2010. Perspective: export expertise. In USDEC: Cheese Market News. Accessed Dec. 12, 2010. http://www.usdec.org/ files/PDFs/Feb10_toolkit.pdf.

Meilgaard, M. M., G. V. Civille, and B. T. Carr. 2007. Descriptive analysis techniques. Page 189-254 in Sensory Evaluation Techniques. 4th ed. CRC Press, Boca Raton, FL.

Nawar, W. W. 1996. Food Chemistry. 3rd ed. CRC Press, New York, NY.

NIST (National Institute of Standards and Technology). 2005. Wiley Registry. NIST Mass Spectral Library. 8th ed. Wiley, Hoboken, NJ.

NMPF (National Milk Producers Federation) and USDEC (United States Dairy Export Council). 2009. Joint comments by the National Milk Producers Federation and the U.S. Dairy Export Council on China's compliance with WTO commitments. Jan. 20, 2011. http://www.nmpf.org/files/file/Dairy\%20Industry\% 200Comments\%20Re\%20China\%20WTO\%20Compliance_092209. pdf.

O'Connor, T. P., and N. M. O'Brien. 2006. Lipid oxidation. Pages 557-600 in Advanced Dairy Chemistry Volume 2: Lipids. 3rd ed. P. F. Fox and P. L. H. McSweeney, ed. Chapman \& Hall, London, UK.

Qi, P., H. Hong, X. Liang, and D. Liu. 2009. Assessment of benzoic acid levels in milk in China. Food Control 20:414-418.

Russell, T. A., M. A. Drake, and P. D. Gerard. 2006. Sensory properties of whey and soy proteins. J. Food Sci. 71:S447-S455.

Sieber, R., U. Bütikofer, and J. O. Bosset. 1995. Benzoic acid as a natural compound in cultured dairy products and cheese. Int Dairy J. 5:227-246.

State Bureau for Quality Supervision, Inspection and Quarantine. 1996. Hygienic standards for the use of food additives. National Standard of the People's Republic of China GB 2760. Standards Press of China, Beijing.

Tfouni, S. A. V., and M. C. F. Toledo. 2002. Determination of benzoic and sorbic acids in Brazilian food. Food Contr. 13:117-123.

Tomaino, R. M., L. G. Turner, and D. K. Larick. 2004. The effect of Lactococcus lactis starter cultures on the oxidative stability of liquid whey. J. Dairy Sci. 87:300-307.

US FDA. 2010a. 21 CFR 184.1021: Benzoic acid. Accessed Sep. 20 , 2010. http://www.accessdata.fda.gov/scripts/cdrh/cfdocs/cfcfr/ CFRSearch.cfm?fr $=184.1021$

US FDA. 2010b. 21 CFR 184.1157: Benzoyl peroxide. Accessed Sep. 20, 2010. http://www.accessdata.fda.gov/scripts/cdrh/cfdocs/cfcfr/CFRSearch.cfm?fr $=184.1157$.

US FDA. 2010c. 21 CFR 184.1366: Hydrogen peroxide. Accessed Sep. 20, 2010. http://www.accessdata.fda.gov/scripts/cdrh/cfdocs/cfcfr/CFRSearch.cfm?fr $=184.1366$ 
USDEC (United States Dairy Export Council). 2009. China testing for the presence of benzoic acid. Member Alert. Accessed Dec. 16, 2010. http://usdec.files.cms-plus.com/Member Alert - Benzoic Acid Testing in China.pdf.

Van den Dool, H., and P. D. Kratz. 1963. A generalization of the retention index system including linear programmed gas-liquid partition chromatography. J. Chromatogr. A 11:463-471.

Whitson, M. E., R. E. Miracle, and M. A. Drake. 2010. Sensory characterization of chemical components responsible for cardboard flavor in whey protein. J. Sens. Stud. 25:616-636.

WHO (World Health Organization). 2000. Benzoic acid and sodium benzoate. Concise International Chemical Assessment Document
26. Jan. 20, 2011. http://www.who.int/ipcs/publications/cicad/ cicad26_rev_1.pdf.

Wright, B. J., S. E. Zevchak, J. M. Wright, and M. A. Drake. 2009. The impact of agglomeration and storage on flavor and flavor stability of whey protein concentrate 80 and whey protein isolate. J. Food Sci. 74:S17-S29.

Wright, J. W., M. E. Carunchia Whetstine, R. E. Miracle, and M. A. Drake. 2006. Characterization of cabbage off-flavor in whey protein isolate. J. Food Sci. 71:C86-C90. 